\section{Four Cultivars of Iochroma}

\author{
Alan W. Meerow \\ USDA-ARS-SHRS, National Germplasm Repository, 13601 Old Cutler Road, \\ Miami, FL 33158
}

Rick J. Schoellhorn

University of Florida, Department of Environmental Horticulture, 1545 Fifield Hall, Gainesville, FL 32611

\section{Michael Kartuz \\ Kartuz Greenhouses, 1408 Sunset Drive, Vista, CA 92085-0790}

Additional index words. Solanaceae, tropical shrubs, potted plants, ornamentals, landscape, floriculture, AFLP

Iochroma Benth. (Solanaceae) is a South American genus of some 20 species of shrubs and trees (Huxley et al., 1992). Iochroma cyaneum (Lindl.) M.L. Green is a soft-stemmed, shrubby Ecuadorean endemic generally found between 1800 and $2500 \mathrm{~m}$ elevation. The species is described typically as having dark blue flowers. It is used occasionally as an ornamental shrub in the United Kingdom, southern Europe, Australia, and California. In this paper, we announce the formal recognition and release of three distinct color forms of this species, and a third unidentified Iochroma, all of which have shown remarkable heat tolerance in south Florida, given their native range in elevation. We believe that these fast-growing cultivars have great potential for use as landscape shrubs in USDAHardiness Zones 9B-11 (USDA, 1990), root-hardy perennials in Zones 8B-9A, and as annuals and/or flowering pot plants in all zones.

\section{Origin}

Iochroma cyaneum 'Indigo', 'Royal Blue', 'Sky King', and 'Wine Red' were obtained by the third author before 1993 as unnamed collections of I. cyaneum, and have been grown and sold by his mail-order nursery for several years. All are believed to have originated in Ecuador and were received from various collectors over the years (no further detailed provenance is available). The first author obtained rooted cuttings of each cultivar from Kartuz Greenhouses in 1999 and began 3 years of evaluation. All four have shown a surprising amount of heat tolerance in Miami, given the altitudinal distribution of this species in the Andes. They are propagated readily, very fast-growing, and virtually ever-blooming. We believe that, given their ease of propagation, rapid production rate, and ever-blooming phenology, all four have potential to be mass-marketed for seasonal color in USDA Hardiness Zones beyond their expected low temperature tolerance.

Received for publication 6 Dec. 2002. Accepted for publication 5 Mar. 2003. Mention of a trademark, proprietary product, or vendor does not constitute a guarantee or warranty of the product by the U.S. Dept. of Agriculture and does not imply its approval to the exclusion of other products or vendors that may be suitable.

\section{Description}

A general description of the species is given below, followed by the distinguishing characteristics of the four cultivars. Color descriptions are based on the RHS Color Chart (Royal Horticultural Society, 1998).

Iochroma cyaneum is a soft-stemmed, brittle-wooded, well-branched shrub reaching 1.2 to $1.5 \mathrm{~m}$ in height. The terete stems are green (RHS 144A) and softly pubescent, 5.0- to 8.0-mm diameter when young, eventually becoming RHS grayed-green 196A and up to $1-\mathrm{cm}$ diameter. Leaves are petiolate, exstipulate, simple, alternate, undulate at the margin, ovate-elliptic, RHS green 143A, softly pubescent, apically acute, attenuate at the base, and with the veins impressed on the upper surface. Inflorescences are axillary umbels on new wood, five to 20 flowered. Flowers are pedicellate, pendulous, pentamerous; the sepals connate for most of their length, split apically into five acute lobes. The corolla is tubular, the petals fused throughout most of their length, slightly constricted at the throat, flaring to a 10-lobed limb at their apex. The corolla tube is ribbed. The five stamens are attached to the corolla, biseriate in length, and do not exceed the limb. The style just exceeds the stamens in length; the stigma is minutely capitate, RHS green 139A, and less than $1 \mathrm{~mm}$ wide. The ovary is superior. The fruit is a globose berry, enclosed by the calyx, with numerous small seeds surrounded by pulp. Seed set has not been observed to date in Florida.

Iochroma cyaneum 'Indigo' (Fig. 1) has petioles 1.0 to $1.5 \mathrm{~cm}$ long and leaf blades 5.5 to $6.8 \mathrm{~cm}$ long, 3.6 to $4.2 \mathrm{~cm}$ wide. Pedicels are 12 to $17 \mathrm{~mm}$ long. The calyx is 7.5 to 10 $\mathrm{mm}$ long. The flowers are 3.8 to $4.4 \mathrm{~cm}$ long measured from the base of the calyx, 3.5 to 4.0 $\mathrm{mm}$ wide at the base of corolla, widening in the apical 8 to $10 \mathrm{~mm}$ to a 12 - to 14 -mm-wide, 10-lobed limb. Alternate lobes are keeled on their interior surface. When the flowers first open, they are RHS purple 79A; at anthesis they lighten to $78 \mathrm{~A}$ to $\mathrm{B}$.

Iochroma cyaneum 'Royal Blue' (Fig. 2) has petioles 1.0 to $1.5 \mathrm{~cm}$ long, and leaf blades 5.0 to $10 \mathrm{~cm}$ long, 3.5 to $4.5 \mathrm{~cm}$ wide. Pedicels are 15 to $25 \mathrm{~mm}$ long. The calyx is 12 to $14 \mathrm{~mm}$ long. The flowers are 4.5 to 4.8 $\mathrm{cm}$ long measured from the base of the calyx, 4.0 to $4.5 \mathrm{~mm}$ wide at the base of the corolla, widening in the apical 8 to $10 \mathrm{~mm}$ to a 12 - to 14-mm-wide, 10-lobed limb. Alternate lobes are keeled on their interior surface. When the flowers first open, they are RHS violet-blue 93A; at anthesis they lighten to 90C.

Iochroma cyaneum 'Sky King' (Fig. 3) has petioles 1.0 to $2.0 \mathrm{~cm}$ long, and leaf blades 4.5 to $6.0 \mathrm{~cm}$ long, 3.0 to $3.6 \mathrm{~cm}$ wide. Pedicels are 20 to $23 \mathrm{~mm}$ long. The calyx is 9 to $10 \mathrm{~mm}$ long. The flowers are 4.5 to 4.8 $\mathrm{cm}$ long measured from the base of the calyx, 4.0 to $5.0 \mathrm{~mm}$ wide at the base of the corolla, widening in the apical 8 to $10 \mathrm{~mm}$ to a 10 - to 12-mm-wide, 10-lobed limb. Alternate lobes are keeled on the interior surface. When the flowers first open, they are RHS violet $88 \mathrm{C}$; at anthesis they lighten to 88D.

Iochroma 'Wine Red' (Fig. 4) has not yet been identified as to species, and DNA amplified fragment length polymorphism (AFLP) profiles (see below) suggest that it is a taxon other than I. cyaneum. 'Wine Red' has hairier young stems than the previous three cultivars, petioles 9.0 to $16 \mathrm{~mm}$ long, and leaf blades 8.0 to $13.0 \mathrm{~cm}$ long, 3.8 to $5.0 \mathrm{~cm}$ wide. Pedicels are 11 to $17 \mathrm{~mm}$ long. The calyx is 7 to 8 $\mathrm{mm}$ long. The flowers are 4.0 to $5.0 \mathrm{~cm}$ long measured from the base of the calyx, 4.0 to $4.5 \mathrm{~mm}$ wide at the base of the tube, widening in the apical 8 to $10 \mathrm{~mm}$ to a 7.5 - to $8.5-\mathrm{mm}$ wide, 5- (to 7-) lobed limb. The limb is keeled between the lobes on interior surface. When the flowers first open, they are RHS red-purple $61 \mathrm{~B}$, fading to $64 \mathrm{D}$.

'Royal Blue' has a longer calyx than does any of the other cultivars. 'Wine Red' may be distinguished from the three cultivars of $I$. cyaneum not only by flower color, but also by its larger leaves, pilose young stems, and 5- (to 7-) lobed limb. To date, there is no published treatment of Iochroma that would allow easy identification of an unknown species. The first author has seen I. cyaneum in habitat in Ecuador on multiple occasions, and the first three cultivars described in this paper are readily assignable to that species. Iochroma cyaneum does vary in flower color, and other cultivars have been described in the species, e.g., 'Alba', 'Apricot Belle', and 'Woodcote White' (Ellison, 1995; the latter mislabeled as a cultivar of I. grandiflora). The I. grandiflora pictured by Ellison (1995) appears similar to 'Wine Red', but is definitely not I. grandiflora, a high-elevation scrambling shrub with very large blue flowers (Shaw, 1998; personal observation).

\section{Molecular characterization using AFLPs}

DNA extraction. DNA was extracted from all four cultivars using the Dellaporta (1983) method from $2.0 \mathrm{mg}$ of fresh leaf samples. After drying, the DNA was resuspended in $30 \mu \mathrm{LTE}$, $\mathrm{pH}$ 7.4. DNA concentration was evaluated by gel visualization. Duplicate extractions were performed for each accession.

Amplified fragment length polymorphisms of total DNA from the four cultivars were assayed using fluorescent dye-labeling and 


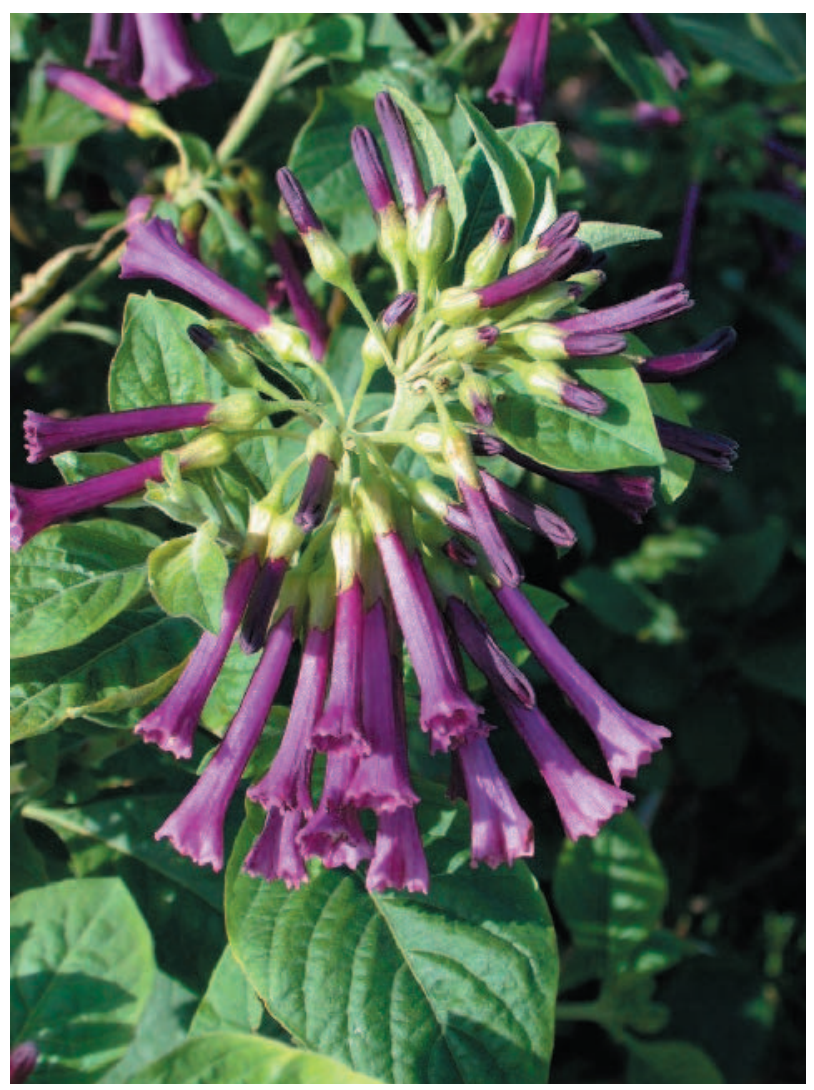

Fig. 1. Iochroma cyaneum 'Indigo'.

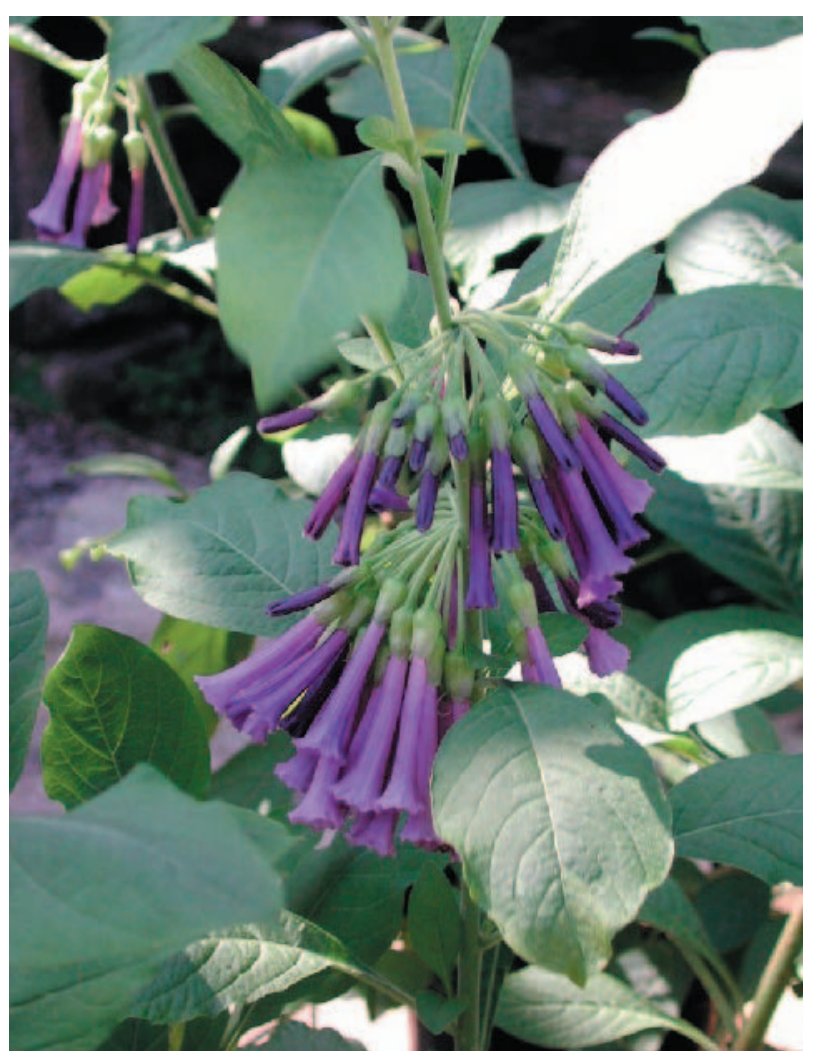

Fig. 2. Iochroma cyaneum 'Royal Blue'.

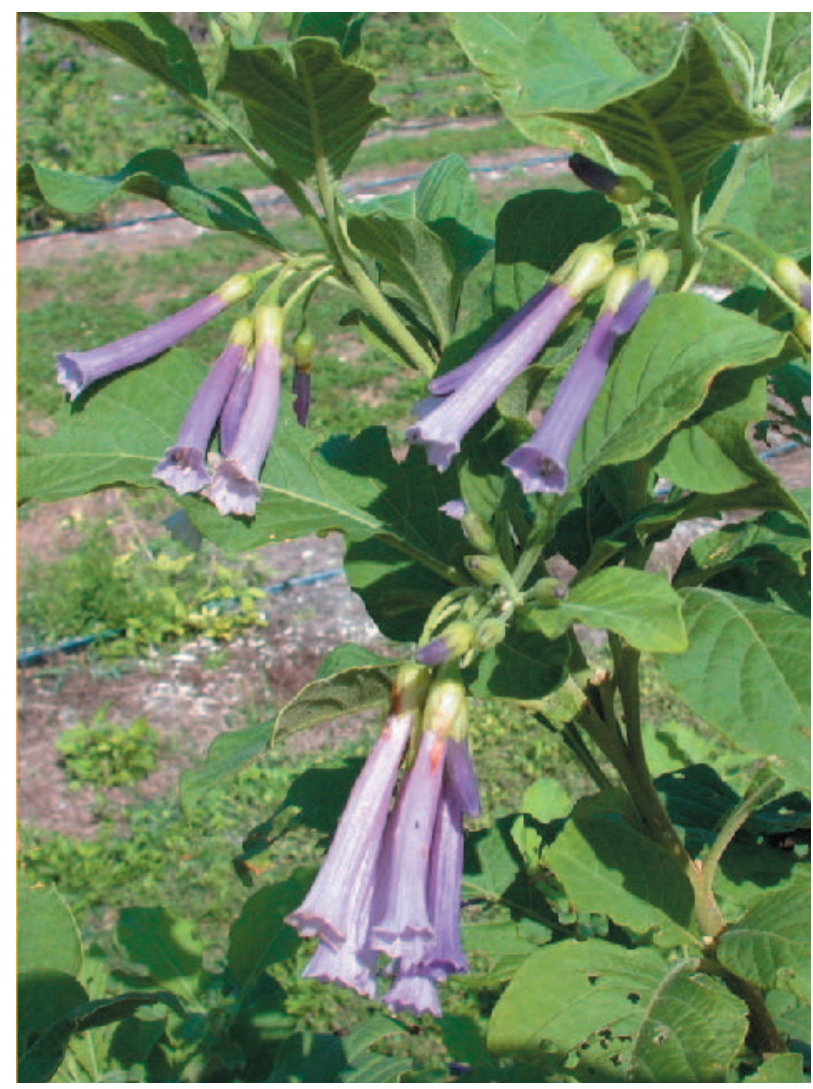

Fig. 3. Iochroma cyaneum 'Sky King'.

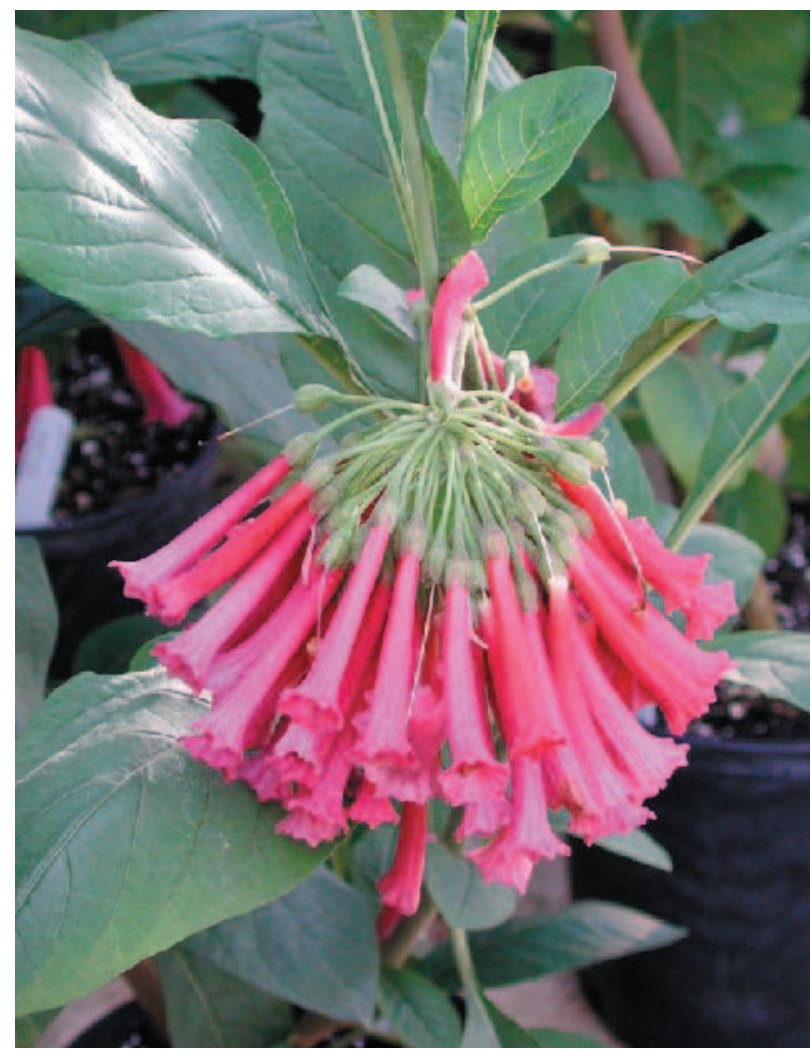

Fig. 4. Iochroma 'Wine Red'. 
Table 1. Primer combinations and number of polymorphic peaks scored in the AFLP analysis of four cultivars of Iochroma cyaneum.

\begin{tabular}{|c|c|}
\hline Primer combination & $\begin{array}{l}\text { No. of polymorphic } \\
\text { peaks scored }\end{array}$ \\
\hline$\overline{E c o R I-A G G ~ J O E ~+~ M s e I-C A A ~}$ & 22 \\
\hline EcoRI-AGG JOE + MseI-CAC & 12 \\
\hline EcoRI-AGG JOE + MseI-CAG & 15 \\
\hline EcoRI-AGG JOE + MseI-CTA & 32 \\
\hline EcoRI-AGG JOE + MseI-CTC & 18 \\
\hline EcoRI-AGG JOE + MseI-CTG & 17 \\
\hline EcoRI-AGG JOE + MseI-CTT & 23 \\
\hline EcoRI-AGC NED + Mse I-CTG & 14 \\
\hline EcoRI-AGC NED + Mse I-CAG & 18 \\
\hline EcoRI-AGC NED + MseI-CTA & 26 \\
\hline EcoRI-AGC NED + MseI-CAA & 21 \\
\hline EcoRI-ACT FAM + MseI-CTG & 19 \\
\hline EcoRI-ACT FAM + MseI-CTC & 19 \\
\hline EcoRI-ACT FAM + MseI-CTA & 15 \\
\hline 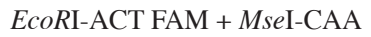 & 17 \\
\hline EcoRI-ACG JOE + Msel-CTT & 28 \\
\hline$E c o R \mathrm{I}-\mathrm{ACG} \mathrm{JOE}+M s e \mathrm{I}-\mathrm{CTG}$ & 28 \\
\hline$E c o R \mathrm{I}-\mathrm{ACG} \mathrm{JOE}+M s e \mathrm{I}-\mathrm{CTC}$ & 35 \\
\hline$E c o$ RI-ACG JOE + MseI-CTA & 16 \\
\hline EcoRI-ACG JOE + MseI-CAG & 21 \\
\hline$E c o \mathrm{RI}-\mathrm{ACG} \mathrm{JOE}+M s e \mathrm{I}-\mathrm{CAC}$ & 23 \\
\hline EcoRI-ACG JOE + MseI-CAA & 22 \\
\hline$E c o$ RI-ACC NED + MseI-CTT & 15 \\
\hline$E c o \mathrm{RI}-\mathrm{ACC} \mathrm{NED}+M s e \mathrm{I}-\mathrm{CTG}$ & 16 \\
\hline$E c o$ RI-ACC NED + MseI-CTC & 8 \\
\hline EcoRI-ACC NED + MseI-CTA & 21 \\
\hline EcoRI-ACC NED + MseI-CAT & 12 \\
\hline$E c o$ RI-ACC NED + MseI-CAG & 23 \\
\hline$E c o \mathrm{RI}-\mathrm{ACC} \mathrm{NED}+M s e \mathrm{I}-\mathrm{CAC}$ & 19 \\
\hline$E c o$ RI-ACA FAM + MseI-CTC & 8 \\
\hline EcoRI-ACA FAM + MseI-CTT & 12 \\
\hline EcoRI-ACA FAM + MseI-CAT & 14 \\
\hline$E c o$ RI-ACA FAM + MseI-CAG & 13 \\
\hline EcoRI-ACA FAM + MseI-CAC & 15 \\
\hline$E c o$ RI-AAG JOE + MseI-CTT & 11 \\
\hline EcoRI-AAG JOE + MseI-CTG & 21 \\
\hline$E c o$ RI-AAG JOE + MseI-CTA & 27 \\
\hline EcoRI-AAG JOE + MseI-CAT & 21 \\
\hline$E c o$ RI-AAG JOE + MseI-CAG & 31 \\
\hline$E c o$ RI-AAG JOE + MseI-CAC & 22 \\
\hline$E c o$ RI-AAG JOE + MseI-CAA & 17 \\
\hline$E c o$ RI-AAC NED + MseI-CTT & 15 \\
\hline$E c o$ RI-AAC NED + MseI-CTG & 15 \\
\hline$E c o$ RI-AAC NED + MseI-CTC & 19 \\
\hline$E c o$ RI-AAC NED + MseI-CAG & 10 \\
\hline$E c o$ RI-AAC NED + MseI-CAA & 14 \\
\hline$E c o$ RI-AAC NED + Mse I-CAC & 7 \\
\hline
\end{tabular}

detection technology. Fluorescent detection was performed on an ABI Prism $3100 \mathrm{Ge}$ netic Analyzer (Applied Biosystems, Foster City, Calif.). The AFLP ${ }^{\mathrm{TN}}$ plant-mapping kit was purchased from Applied Biosystems and the protocol carried out according to manufacturers' directions (Applied Biosystems, 2000). Polymerase chain reactions (PCRs) were performed on an Applied Biosystems GeneAmp 9700.

Sixty-four different primer pair combinations were used for the amplification on all samples. Data were collected using GeneScan software for Windows (version 3.1, Applied Biosystems). The threshold value for peak detection varied per primer pair, ranging between 25 and 40 fluorescent units.

Data analysis. Combined data files containing data for all samples were created with GeneScan analysis software (version 3.7, Applied Biosystems) and further analyzed using Genotyper software for Windows (version 3.7,

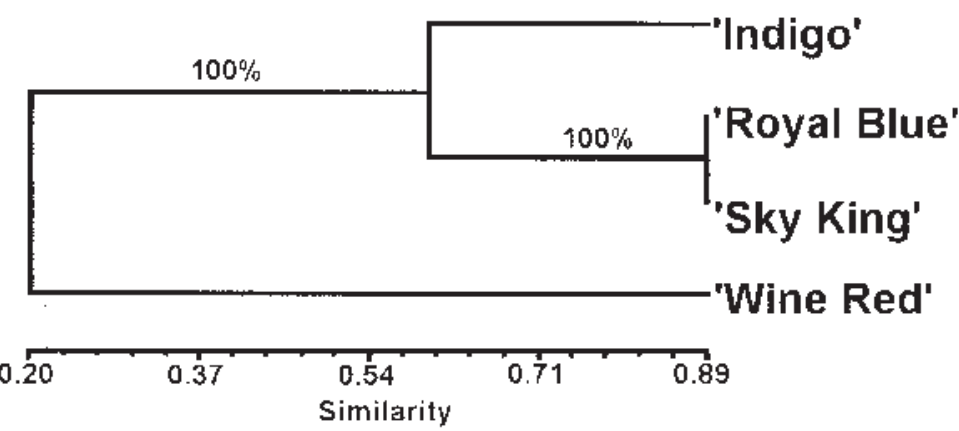

Fig. 5. UPGMA phenogram of Iochroma cultivars based on Nei and Li (1979) similarity coefficients generated from AFLP analysis. Numbers above branches are bootstrap percentages.

Applied Biosystems) for each primer combination. Peaks less than $100 \mathrm{bp}$ and more than 450 bp in size were filtered out, and those differing by less than a base in size were collapsed into the same category. Any peak present in only one of the two replications of any cultivar was disqualified from consideration. Amplification products were scored for presence (1) or absence (0) of peaks. Peaks common to all accessions were considered non-informative. Ultimately, 47 of the 64 primer combinations yielded usable peaks. The total number of polymorphic peak categories was 868 (Table 1). Using the program FreeTree (Pavlicek et al., 1999), a pairwise similarity matrix (Table 2) between genotypes was estimated according to Nei and Li (1979):

$$
S_{i j}=\frac{2 a}{(2 a+b+c)}
$$

where $S_{i j}$ is the similarity between two individuals $i$ and $j, a$ the number of positive peaks shared by both individuals, $b$ the number of peaks present in $i$ and absent in $j$, and $c$ the number of peaks present in $j$ and absent in $i$. Adendrogram (Fig. 5) was constructed using the unweighted pairgroup method(UPGMA; Sneath and Sokal, 1973) and confidence limits on the clusters were determined with 5000 replications of bootstrapping (Felsenstein, 1985).

Bootstrap confidence intervals were $100 \%$ for all clusters based on the AFLP data (Fig. $5)$. Highest similarity (0.8856) was between $I$. cyaneum 'Royal Blue' and 'Sky King' (Fig. 5, Table 2). 'Wine Red' had the lowest similarity coefficients with the other three cultivars (Table 2), and is a distant outlier in the UPGMA dendrogram (Fig. 5). 'Wine Red' had the highest genetic similarity with 'Indigo' (0.2966). Based on these data, coupled with the morphological differences between 'Wine Red' (see above) and other three cultivars, we believe that 'Wine Red' is a form of another species of Iochroma.

\section{Cultural notes}

All four Iochroma cultivars are readily propagated in spring and autumn, and probably at any other time of year. Both softwood and semi-ripened wood cuttings from actively growing plants root within 4 to 6 weeks under intermittent mist, treated with a 5-s basal end dip in $1000-2500 \mathrm{mg} \cdot \mathrm{L}^{-1}$ indolebutyric acid, though percentages were slightly lower at the
Table 2. Pairwise similarity coefficients (Nei and $\mathrm{Li}, 1979$ ) between four cultivars of Iochroma cyaneum.

\begin{tabular}{lccc}
\hline Cultivar & Indigo & Royal Blue & Sky King \\
\hline Royal Blue & 0.6100 & ---- & \\
Sky King & 0.5943 & 0.8856 & --- \\
Wine Red & 0.2966 & 0.1462 & 0.1655 \\
\hline
\end{tabular}

lower concentration. Rooting percentages ranged from $83 \%$ to $94 \%$.

Rooted cuttings should be pinched at the time of transplanting, and again once lateral shoots are 76-101 cm long, in order to produce well-branched plants (we are currently experimenting with growth regulators on all four cultivars). We have trialed three different production regimes. Rooted cuttings placed directly into 2.7-L containers were finished and flowering 8-10 weeks after transplant. Rooted cuttings were also placed into $0.5-\mathrm{L}$ pots, and then transplanted 4 weeks later into 5.4-L containers. These were finished and flowering 10 to 12 weeks after transplant. We also transplanted five rooted cuttings into 5.4-L hanging baskets. Only rooted softwood cuttings (vs. semi-ripened wood) should be used for this purpose. 'Wine Red' and 'Royal Blue' seem most amenable to basket culture, but baskets were no longer attractive after 5 months.

We have successfully grown all four cultivars in 5 aged pine bark: 4 coconut coir dust: 1 coarse sand (by volume), amended with 5.0 $\mathrm{kg} \cdot \mathrm{m}^{-3} 17 \mathrm{~N}-2.3 \mathrm{P}-10 \mathrm{~K}$ Osmocote (Scotts, Milpitas, Calif.), $4.2 \mathrm{~kg} \cdot \mathrm{m}^{-3}$ dolomite, and $1.2 \mathrm{~kg} \cdot \mathrm{m}^{-3}$ Micromax (Scotts). We have also lightened this mix with $25 \%$ coarse perlite (by volume) with similar results. A pH of 6.0 to 6.5 is essential. Substrate $\mathrm{pH}$ in excess of 7.0 results in chronic iron-deficiency symptoms.

If allowed to become potbound, all four cultivars of I. cyaneum exhibit "hard," woody growth, and drop their lower leaves. Such plants can be renovated by cutting the stems back to a few nodes, disrupting and pruning the dense root mass, and transplanting into fresh substrate.

Trial blocks of all four cultivars were established in the ground at the National Germplasm Repository, Miami, from plants established in 5.4-L containers in Apr. 2001 in both amended (10-year-old aged compost from vegetative solid waste) and unamended soil. The plants in amended substrate are 1 to $1.5 \mathrm{~m}$ 
tall and have been in continuous bloom. The plants in unamended substrate $(\mathrm{pH}=8.5-9.0)$ are consistently iron deficient and flower only sporadically.

In the landscape, all four cultivars of I. cyaneum should be situated in full sun, on soils amended with organic matter, and fertilized regularly. In sites with lower light levels, stem internodes elongate and flowering decreases. Once each year the plants should be cut back to one-half to two-thirds of their height. The soil should be evenly moist throughout the growing season; irrigation can be reduced during the winter.

Pest and disease problems are few. Tobacco [Manduca sexta (Linnaeus)] and tomato [Manduca quinquemaculata (Haworth)] hornworms will feed on I. cyaneum, and occasional light infestations of various homopteran insects have been observed. Iochroma cyaneum is potentially susceptible to tobacco mosaic virus (TMV), and nursery workers who use tobacco should not propagate the plants, or should at least wash their hands with $95 \%$ EtOH before doing so.

The rapid rate of growth, ease of propaga- tion, and long flowering season suggest that these I. cyaneum cultivars could be marketed as annual plants beyond their expected hardiness range (USDAZone 9B-11, Huxley et al., 1992; Shaw, 1998). We are hopeful that our experiments with growth regulators may also support their future use as flowering potted plants for the mass market.

\section{Availability}

Small quantities of each of the four cultivars are available for research purposes only by request through the USDA-ARS National Plant Germplasm System (http://www.arsgrin.gov/npgs/) as accessions PI 632348 ('Indigo'), PI 632350 ('Royal Blue'), PI 632357 ('Sky King'), and PI 632349 ('Wine Red'). The third author should be contacted for commercial quantities.

\section{Literature Cited}

Applied Biosystems. 2000. AFLP plant mapping protocol. Appl. Biosystems, Foster City, Calif.

Dellaporta, S.L., J. Wood, and J.B. Hicks. 1983. Isolation of DNA from higher plants. Plant Mol.
Biol. Rptr. 4:19-21.

Ellison, D. 1995. Cultivated plants of the world Flora Publ. Intl., Brisbane, Australia.

Felsenstein J. 1985. Confidence limits on phylogenies: An approach using the bootstrap. Evolution 39:783-791.

Huxley, A.J., M. Griffiths, and M. Levy. 1992. The new Royal Horticultural Society dictionary of gardening. Stockton Press, New York.

Nei, M. and W. Li. 1979. Mathematical model for studying genetic variation in terms of restriction endonucleases. Proc. Natl. Acad. Sci. (USA) 76: 5269-5273.

Pavlicek, A., S. Hrda, and J. Flegr. 1999. FreeTree - Freeware program for construction of phylogenetic trees on the basis of distance data and bootstrap/jackknife analysis of the tree robustness. Application in the RAPD analysis of the genus Frenkelia. Folia Biologica (Prague) 45: 97-99.

Royal Horticultural Society. 1998. RHS Color Chart. Royal Hort. Soc., London.

Shaw, J.M.H. 1998. A review of Iochroma in cultivation. New Plantsman 5(3):154-191.

Sneath, P.H.A. and R.R. Sokal. 1973. Numerical taxonomy. Freeman, San Francisco.

U.S. Dept. of Agriculture. 1990. USDA plant hardiness zone map. USDA Misc. Publ. No. 1475, Washington, D.C. 